\title{
ANIMAL RESEARCH PAPER The associations of management and demographic factors with technical, allocative and economic efficiency of Irish dairy farms
}

\author{
E. KELLY ${ }^{1,2 *}$, L. SHALLOO ${ }^{1 *}$, U. GEARY ${ }^{1}$, A. KINSELLA ${ }^{3}$, F. THORNE ${ }^{4}$ AND M. WALLACE ${ }^{2}$ \\ ${ }^{1}$ Livestock Systems Research Department, Animal and Grassland Research and Innovation Centre, Teagasc, Moorepark, \\ Fermoy, Co. Cork, Ireland \\ ${ }^{2}$ School of Agriculture, Food Science and Veterinary Medicine, University College Dublin, Belfield, Dublin 4, Ireland \\ ${ }^{3}$ Rural Economy Research Centre, Teagasc, Athenry, Co. Galway, Ireland \\ ${ }^{4}$ Rural Economy Research Centre, Teagasc, Kinsealy, Dublin 17, Ireland
}

(Received 14 June 2011; revised 14 November 2011; accepted 5 March 2012; first published online 4 April 2012)

\section{SUMMARY}

The phasing out of the European Union (EU) milk quota will create opportunities for producers to expand without the constraint of quota which has limited expansion since 1984. Therefore, it will be necessary for Irish dairy producers to become more competitive by increasing performance using the least amount of inputs per unit of output and maximizing the level of technical and economic efficiency. The objectives of the current study were to measure technical, allocative and economic efficiency, and to investigate the associations of key management, qualitative and demographic characteristics on efficiency. Efficiency scores were calculated using the nonparametric methodology data envelopment analysis (DEA). The DEA results showed that on average the sample of Irish dairy producers were not fully efficient in 2008 with technical, allocative and economic efficiency results under variable returns to scale (VRS) of $0.771,0.740$ and 0.571 , respectively. In a second stage analysis, Tobit regressions were used to determine the associations of key variables with the technical, allocative and economic efficiency scores. The efficiency scores were included as dependent variables and the key independent variables were a variety of management and demographic variables. Mean calving date, number of grazing days, breeding season length, milk quality, discussion group membership and soil quality were all associated with technical and economic efficiency. Milk recording, use of artificial insemination (Al) and level of dairy specialization were associated with allocative and economic efficiency only. Age and age squared were the only significant demographic associations with the efficiency scores.

\section{INTRODUCTION}

The Irish and European Union (EU) dairy industry is in a period of considerable change, moving from a period of protection towards an eventual situation where milk quota will no longer be limiting milk production. This will create significant opportunities for dairy producers to expand their production. However, support from the $\mathrm{EU}$ is likely to diminish further, as quota is removed and milk price volatility will become a prominent feature of the production system as the principles of global supply and demand become an integral part of EU markets. It has been estimated that by 2050 that the world will have to produce $70-100 \%$ more food (O'Brien 2011),

* To whom all correspondence should be addressed. Email: eoin. kelly@teagasc.ie, laurence.shalloo@teagasc.ie which will require producers to maximize output using the least inputs. It is also important to balance the demand for greater productive efficiency with the need to conserve the environment. For example, environmental issues such as the reduction of greenhouse gas emissions by 2020 and potential pollution problems from excessive nitrates and phosphates are also factors that must be considered.

Risk factors such as milk-price fluctuations will force producers to focus on becoming more technically and economically efficient. The profitability of specialist dairy farms in Ireland decreased between 2007 and 2008 with family farm income (FFI) reduced by $10 \%$, due mainly to increases in direct and overhead costs (Connolly et al. 1998-2008). The key to reducing the overall costs of production is to maximize efficiency in 
the use of inputs. This can be done by adopting the best practice management techniques utilized by the most efficient producers; as studies by Tauer (1993), Rougoor et al. (1998) and Hansson \& Öhlmér (2008) have concluded the reasons for substantial differences between efficient and inefficient producers were attributed to poor management.

Economic efficiency or overall efficiency can be defined as the product of allocative and technical efficiency (Farrell 1957). Technical efficiency can be described as the capacity of a business unit to produce the maximum possible output from a given mix of inputs and allocative efficiency as the selection of inputs based on the market price that they hold (Farrell 1957). Much of the efficiency measurement work on dairy farms has used frontier methodologies such as stochastic frontier analysis (SFA) and data envelopment analysis (DEA). Hansson \& Öhlmér (2008) used DEA to investigate the effect of management practices such as feeding, breeding and animal health on the whole farm efficiencies of Swedish dairy farms. In a separate study carried out by Tauer \& Mishra (2006), the cost efficiency of American dairy farms using stochastic cost functions was quantified. Stokes et al. (2007) used both physical and financial information to identify both technical and cost efficient dairy producers using DEA. Unlike previous studies mentioned, the current study is focused on efficiency allocated to the dairy enterprise only and the data used are from a group of predominantly grass-based dairy producers constrained by quota, unlike most international studies. Unlike previous Irish studies by Kelly et al. (2011) and Carroll et al. (2007), which focused only on technical efficiency, the current study also investigated allocative and economic efficiency.

The objectives of the current study were to measure technical, allocative and economic efficiency for a sample of Irish specialist dairy farms and to investigate the associations of key management, qualitative and demographic characteristics with technical, allocative and economic efficiencies.

\section{MATERIALS AND METHODS}

Methodology

DEA is a non-parametric method of efficiency analysis employing linear programming techniques (Charnes et al. 1978). The methodology works by estimating a best practice frontier, which is derived by enveloping the inputs and outputs of the most efficient

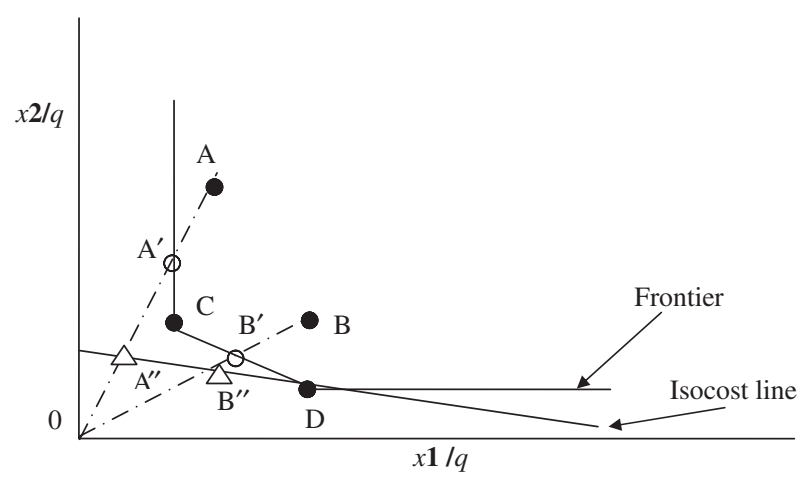

Fig. 1. Cost efficiency with DEA. - A, B, C and $\mathrm{D}=$ decision-making units $(\mathrm{DMU}) ; O \mathrm{~A}^{\prime}$ and $\mathrm{B}^{\prime}=$ projected point on the frontier which is used to indicate level of inefficiency; $\triangle A^{\prime \prime}$ and $B^{\prime \prime}=$ projected point on the frontier if DMU A or B became economic efficient; $\square X_{1}$ and $\mathrm{X}_{2}=$ inputs; $\mathbf{\square}=$ output.

decision-making units (DMU). Those DMU lying on the frontier are classified as efficient relative to the sample, with a score of 1 , while those below the frontier are regarded as inefficient, with a score of less than 1. All efficiency scores in DEA range between 0 and 1. The level of inefficiency for a DMU is the distance from that DMU's production point to the efficient frontier, which is the amount of inputs that can be contracted without adjusting output.

The DEA model can be either input- or outputorientated. According to Coelli et al. (2005) both output- and input-orientated models will recognize the same set of efficient DMU. Input-orientated models have been used in the majority of previous studies similar to the current one and it was noted by Coelli et al. (2005) that orientation should be selected based on which quantities the manager has most control over. In the current study, the focus is on technical and economic efficiency and minimizing input costs, therefore, since producers have most control over the amount of inputs used when limited by milk quota, input-orientated models are used.

\section{Economic efficiency in DEA}

Figure 1 provides a graphical example of DEA for an input-orientated model following that of Coelli et al. (2005) using two inputs, $x_{1}$ and $x_{2}$, and one output, $q$. Figure 1 contains a technically efficient frontier (isoquant) and a cost line that is tangential to the technical efficiency frontier. Farms $C$ and D in Fig. 1 lie on the frontier and so are technically efficient. Farm D is the only economically efficient farm, as it also lies on the isocost line. Farms A and B lie to the right of the 
frontier and so are (i) technically inefficient relative to Farms C and D and (ii) economically inefficient relative to Farm D. Technical efficiency of Farm B is measured along the ray of the origin to that point off the efficiency frontier and is given by the ratio:

$\theta=0 \mathrm{~B}^{\prime} / \mathrm{OB}$

Economic efficiency for Farm B is similar to how technical efficiency is measured except that it is the distance from the point $B$ to the isocost line which is given by the radial distance:

$\theta=0 \mathrm{~B}^{\prime \prime} / \mathrm{OB}$

Since allocative efficiency is economic efficiency divided by technical efficiency, it can be calculated as the ratio:

$\theta=\left(\mathrm{OB}^{\prime \prime} / \mathrm{OB}\right) /\left(\mathrm{OB}^{\prime} / \mathrm{OB}\right)$

\section{Mathematical model}

In the current analysis, an input-orientated DEA model was estimated under the assumption of variable returns to scale (VRS) such that every increase in input would not result in a proportional increase in output (Banker et al. 1984). The main advantage of this model was that the scale-inefficient farms would only be compared to efficient farms of similar size. This was important in the current study because the farms in the dataset utilized operated at different levels of scale; therefore, VRS was the most appropriate assumption. The VRS assumption works by firstly assuming that there are I farms with $N$ inputs and $M$ outputs and they are represented from the $i$ th farm by the vectors $x i$ and qi. Data for the ith farm is represented by the $N I$ input matrix $X$ and the $M I$ output matrix $Q$. To assume VRS that all farms are not operating at optimal scale, the convexity constraint $I 1^{\prime} \lambda=1$ is used, which benchmarks farms against farms of similar size by enveloping the data points tighter than under the assumption of VRS, thereby comparing farms of similar size.

\section{Technical efficiency model}

The following is an input-orientated VRS DEA model expressed as follows by Coelli et al. (2005):

$$
\begin{aligned}
& \operatorname{Min}_{\varnothing, \lambda} \theta \\
& \text { St }-q i+Q \lambda \geqslant 0 \\
& \theta x i-X \lambda \geqslant 0 \\
& I 1^{\prime} \lambda=1 \\
& \lambda \geqslant 0
\end{aligned}
$$

where $I \times 1$ is an $/ 1$ vector of ones, $\theta$ is a scalar and $\lambda$ forms part of the convexity constraint that efficiency score is between 0 and 1 .

\section{Economic efficiency model}

With the same assumptions as the above technical efficiency model, the following is the economic efficiency model used in the analysis using a cost minimization model following that of Coelli et al. (2005):

$$
\begin{aligned}
& \operatorname{Min}_{\lambda, x i}^{*} w_{i}^{\prime} x_{i}^{*} \\
& \text { St }-q_{i}+Q \lambda \geqslant 0 \\
& x_{i}^{*}-X \lambda \geqslant 0 \\
& I 1^{\prime} \lambda=1 \\
& \lambda \geqslant 0
\end{aligned}
$$

where $w_{i}$ is an $N \times 1$ vector of input prices for the $i$ th firm, $x_{i}^{*}$ is the cost minimizing vector of input quantities for the ith firm with the input prices and the level of output and all other quantities are as per the technical efficiency mathematical model above, $\lambda$ is an $I \times 1$ vector of constraints.

Economic efficiency is the ratio of minimum to observed cost and can be calculated with the following ratio:

$$
\mathrm{EE}=w_{i}^{\prime} x_{i}^{*} / w_{i}^{\prime} x_{i}
$$

\section{Allocative efficiency model}

Since economic efficiency is the product of technical efficiency and allocative efficiency (Farrell 1957), allocative efficiency can be calculated with the ratio:

$\mathrm{AE}=\frac{\mathrm{EE}}{\mathrm{TE}}$

Like the technical efficiency score, both economic and allocative efficiency scores range between 0 and 1 .

Technical, allocative and economic efficiencyscores were calculated in the first stage using DEA software, DEAP version 2.1 developed by Coelli (1996).

\section{Dataset}

Data from the National Farm Survey (NFS) in 2008 (Connolly et al. 1998-2008) were utilized in the current analysis. The NFS is an annual survey of c. 1200 farms weighted by size and system to represent a whole population of 104800 farms in Ireland. For more information on the NFS, see Connolly et al. (1998-2008). The current study uses data for the sub-sample of 324 
Table 1. Allocation keys used to define variables associated with the dairy enterprise

\begin{tabular}{|c|c|}
\hline Variable & Allocation key \\
\hline Land & $\begin{array}{l}\text { Owned and rented* (physical and } \\
\text { financial) }\end{array}$ \\
\hline Cow & $\begin{array}{l}\text { Average number of dairy cows* } \\
\text { (physical and financial) }\end{array}$ \\
\hline Labour & $\begin{array}{l}\text { Labour units* (physical and } \\
\text { financial) }\end{array}$ \\
\hline Concentrate & $\begin{array}{l}\text { Dairy concentrate* (physical and } \\
\text { financial) }\end{array}$ \\
\hline Fertilizer & $\begin{array}{l}\text { Dairy fertilizer* (physical and } \\
\text { financial) }\end{array}$ \\
\hline $\begin{array}{l}\text { Other direct and } \\
\text { overhead costs }\end{array}$ & $\begin{array}{l}\text { Dairy direct costs* (minus costs for } \\
\text { concentrate and fertilizer) + total } \\
\text { overhead costs } \times \text { dairy proportion } \\
\text { of gross output (minus cost of } \\
\text { labour) }\end{array}$ \\
\hline Milk solids & $\begin{array}{l}\text { Total milk solids* produced and sold } \\
\text { (physical and financial) }\end{array}$ \\
\hline Other output & $\begin{array}{l}\text { Value of livestock sales from the } \\
\text { dairy enterprise* }\end{array}$ \\
\hline
\end{tabular}

* Allocated in National Farm Survey (Connolly et al. 19982008).

dairy producers (including both specialist and nonspecialist dairy producers), which is statistically representative of the dairy population for the year 2008.

\section{Data envelopment analysis: inputs and outputs}

All inputs and outputs related to the dairy enterprise only. Inputs such as land, cow numbers, labour and direct costs were already collected by the NFS by dairy enterprise. For overhead costs that were not collected by the dairy enterprise, the share apportioned to the dairy enterprise was determined via allocation based on proportion of gross output coming from the dairy enterprise (see Table 1). This allocation method has been used in previous studies by Smyth et al. (2009), Donnellan et al. (2011), Thorne (2004) and Fingleton (1995). Since dairy inputs and outputs were allocated to the dairy enterprise only, specific dairy enterprise efficiency was measured. Descriptive statistics for all inputs and outputs used in the DEA models are shown in Table 2.

\section{Inputs}

Physical and financial values of land, dairy livestock units, labour, concentrate, fertilizer and other direct and overhead costs were considered as inputs. Land area included both owned and rented land used by the dairy enterprise. The financial element of land value was included based on an NFS estimate of the market value of purchased land. Dairy livestock units were the average number of dairy livestock units, including dairy cows milked during the year and any other stock used in the dairy enterprise, with the price per dairy livestock unit included as the value of total livestock divided by the number of dairy livestock units in 2008.

Physical and financial quantities of purchased fertilizer, purchased concentrate and total labour units used by the dairy enterprise were included. Prices were included per $\mathrm{kg}$ of concentrate and fertilizer and per full time equivalent (FTE) unit of labour. Labour was expressed in total farm labour units and quantified in accordance with NFS specifications including paid (hired labour) and unpaid (family) labour.

Other direct and overhead costs were included (e.g. depreciation, veterinarian and animal health costs, electricity, repairs, miscellaneous costs, etc. attributed to the dairy enterprise).

\section{Outputs}

The outputs used were $\mathrm{kg}$ of milk solids (protein and fat) sold that were produced on the farm and the value of other output from subsidiary dairy farm enterprises. Milk payment systems in Ireland are centred on both protein and fat, with processors either paying on a $\mathrm{kg}$ of milk solids basis minus a processing charge, or on a volume of milk produced with a differential bonus for milk solids composition. Price information for milk solids was generated on a per $\mathrm{kg}$ basis using the average price in 2008 per $\mathrm{kg}$ produced for each producer. Since not all output was generated from milk sold, the financial value of other dairy farm output, including subsidiary dairy livestock sales, was also included as an output.

Second stage analysis - statistical analysis

As differences in efficiency have been widely attributed to differences in management practices, a second stage regression analysis was undertaken. The objective was to identify the key management and demographic factors associated with differences in efficiency.

\section{Variables used}

The independent variables presented in Table 3 that were used in the regression are divided into 
Table 2. Descriptive statistics of input and output variables used in the efficiency models

\begin{tabular}{llllll}
\hline \hline Variables & Units & Mean & S.D. & Minimum & Maximum \\
\hline Inputs & & & & & \\
Land & ha & 34 & $18 \cdot 4$ & 2 & 119 \\
Labour & FTE & $1 \cdot 1$ & $0 \cdot 52$ & $0 \cdot 0$ & $3 \cdot 9$ \\
Livestock units & & 60 & $35 \cdot 5$ & 3 & 233 \\
Fertilizer & $\mathrm{kg}$ & 5159 & 3672 & 73 & 19337 \\
Concentrate & $\mathrm{kg}$ & 60114 & 57961 & 900 & 423100 \\
Other costs & $€$ & 48629 & 39557 & 2034 & 285114 \\
Land & $€ /$ ha & 12336 & 6502 & 15000 & 15000 \\
Cow & $€ / \mathrm{cow}$ & 947 & 188 & 115 & 2110 \\
Labour & $€ /$ FTE & 2012 & 4104 & 0 & 27976 \\
Fertilizer & $€ / \mathrm{kg}$ & $1 \cdot 3$ & $0 \cdot 29$ & $0 \cdot 7$ & $3 \cdot 0$ \\
Concentrate & $€ / \mathrm{kg}$ & $0 \cdot 3$ & $0 \cdot 05$ & $0 \cdot 1$ & $0 \cdot 9$ \\
Milk solids $(\mathrm{MS})$ & $\mathrm{kg}$ & 18841 & 12111 & 0 & 81957 \\
Other output & $€$ & 10166 & 11151 & 0 & 93192 \\
Outputs & & & & & \\
MS price/kg & $€ / \mathrm{kg} \mathrm{MS}$ & $4 \cdot 6$ & $0 \cdot 22$ & $4 \cdot 0$ & $5 \cdot 4$ \\
Stocking rate & $\mathrm{EU} / \mathrm{ha}$ & $1 \cdot 8$ & $0 \cdot 58$ & $0 \cdot 6$ & $6 \cdot 8$ \\
Solids/cow & $\mathrm{kg} / \mathrm{cow}$ & 319 & 93 & 17 & 545 \\
Solids/ha & $\mathrm{kg} / \mathrm{ha}$ & 620 & 334 & 33 & 2546 \\
\hline \hline
\end{tabular}

two groupings: management and demographic variables, each of which is discussed below and were regressed against technical, allocative and economic efficiency.

\section{Management variables}

Grazing season length was the average number of $24 \mathrm{~h}$ periods the dairy herd spent at grass for the year.

Milk quality was the average financial reward of milk bonuses and the economic loss through milk penalties for the year. The value of milk bonuses and penalties varied, because producers did not all supply the same processor.

Artificial insemination (AI) use was included to investigate the associations with efficiency and Al use.

Milk recording was included to see if producers who were using this service to monitor individual cow performance had increased levels of efficiency.

Discussion group membership was investigated, comparing the effects of being a member of a discussion group $v$. not being a member.

Dairy specialization was investigated by using the proportion of gross output attributed to dairy and identifying the association with efficiency with dairy specialization.

Mean calving date was analysed by comparing five different mean calving categories. The mean calving dates were before 14 February, between 14 February and 1 March, between 2 March and 17 March, between 18 March and 31 March and finally mean calving after 1 April. The final mean calving date of after 1 April provided the base category to estimate the association with efficiency of calving earlier than 1 April relative to after. To investigate calving compaction, breeding season length was also included as a variable in the analysis.

Soil was represented by the NFS classification of land quality, which is represented by a scale of $1-5$. The best soil category, with an index of 1 , highlights the soil with most uses and the worst soil category, with an index of 5 , highlights soil with the most limited number of uses. The worst soil class was used as the base category in order to investigate the association of having greater soil quality on efficiency levels.

\section{Demographic variables}

The association of efficiency with demographic variables such as age, age squared (to minimize the nonlinear effects of the model) and marital status, whether the producer had contact with advisory services and participation in off-farm employment were all investigated.

\section{Tobit regression}

As DEA generates efficiency scores that are censored towards the upper boundaries of 1 with a positive 
Table 3. Descriptive statistics of variables used in the Tobit regression

\begin{tabular}{|c|c|c|c|}
\hline Variable & Description & Number & Mean \\
\hline Grazing days & Number of full days grazing & 315 & 226 \\
\hline Breeding length & Number of days to complete breeding & 312 & 142 \\
\hline Dairy proportion Gross output & Proportion gross output from dairy enterprise & 324 & $0 \cdot 636$ \\
\hline Milk penalties & $(€)$ & 324 & 500 \\
\hline Milk bonuses & $(€)$ & 324 & 1279 \\
\hline \multirow[t]{2}{*}{ Milk recording } & 1 if YES & 135 & \\
\hline & 0 if $\mathrm{NO}$ & 189 & \\
\hline \multirow[t]{2}{*}{ Al } & 1 if YES & 258 & \\
\hline & 0 if $\mathrm{NO}$ & 66 & \\
\hline \multirow[t]{2}{*}{ Discussion group member } & 1 if YES & 96 & \\
\hline & 0 if $\mathrm{NO}$ & 228 & \\
\hline \multirow[t]{5}{*}{ Mean calving date } & 1 if calving $\leqslant 14$ Feb & 23 & \\
\hline & 2 if calving $\leqslant 1$ Mar & 59 & \\
\hline & 3 if calving $\leqslant 17$ Mar & 109 & \\
\hline & 4 if calving $\leqslant 31$ Mar & 49 & \\
\hline & 5 if calving $\geqslant 1 \mathrm{Apr}$ & 84 & \\
\hline \multirow[t]{5}{*}{ Soil quality } & $1-6$ with 1 an indication of best soil with & $1=154$ & \\
\hline & widest range of use and 6 the poorest soil quality & $2=40$ & \\
\hline & with most limited range of use & $3=43$ & \\
\hline & & $4=67$ & \\
\hline & & $5=20$ & \\
\hline \multirow[t]{2}{*}{ Teagasc member } & 1 if YES & 230 & \\
\hline & 0 if $\mathrm{NO}$ & 94 & \\
\hline Age & Age of operator (years) & & 52 \\
\hline Age squared & Years squared & & 2697 \\
\hline \multirow[t]{2}{*}{ Off-farm employment } & 1 if YES & 48 & \\
\hline & 0 if $\mathrm{NO}$ & 276 & \\
\hline \multirow[t]{2}{*}{ Married } & 1 if YES & 251 & \\
\hline & 0 if $\mathrm{NO}$ & 73 & \\
\hline
\end{tabular}

probability a Tobit analysis is possible (Hoff 2007). Tobit regression has been the most common method used in DEA studies as a second stage analysis to regress independent variables on the efficiency score. Alternative regression techniques such as ordinary least squares (OLS) are not suitable due to the fact that the error term in the OLS regression models would not be normally distributed and would predict results outside the DEA rationale of between 0 and 1 .

To investigate the stability of model coefficients, variables in the current analysis were introduced into the model in five different groupings, thus developing five different regression models. Model 1 accounted for management factors including number of grazing days, milk quality, breeding season length and level of dairy specialization. The second model added whether or not the producer was using services such as $\mathrm{Al}$, milk recording and being a member of a discussion group. Model 3 included mean calving date, model 4 added soil quality to incorporate land quality differences and finally model 5 included demographic variables all together with the variables used in the previous models. This approach was used previously by Hansson (2008). A Tobit regression model was fitted through the explanatory variables described in Table 4 using PROC LifeReg of SAS (SAS Institute Inc. 2006) and the model used which follows that of Barnes (2006) can be written as

$$
\begin{aligned}
Y & =Y^{*} \text { for } Y^{*}>0 \\
Y & =0 \text { for } Y^{*} \leqslant 0 \\
Y^{*} & =b^{\prime} x+u
\end{aligned}
$$

where the dependent variable is given by the latent variable $Y^{*}, Y$ is censored efficiency score and is equal to latent variable when efficiency score is greater than 0 or equal to 0 , the parameter vector is $b$, the regression 
Table 4. DEA Efficiency scores under VRS*

\begin{tabular}{lccc}
\hline \hline & TE† & AE‡ & EE \\
\hline Average & 0.77 & 0.74 & 0.57 \\
Minimum & 0.11 & 0.21 & 0.09 \\
Maximum & 1.00 & 1.00 & 1.00 \\
S.D. & 0.182 & 0.159 & 0.195 \\
Skewness & -0.96 & -0.70 & 0.11 \\
\hline \hline
\end{tabular}

* VRS, variable returns to scale.

$+\mathrm{TE}$, technical efficiency score.

‡AE, allocative efficiency score.

$\S E E$, economic efficiency score.

variable vectors given by $x$ and the distributed error term given by $u$.

\section{RESULTS}

\section{Efficiency scores}

Technical, allocative and economic efficiency scores for 324 Irish dairy farms were calculated and descriptive statistics of the DEA results are shown in Table 4. A frequency distribution of the results is shown in Fig. 2.

\section{Technical efficiency}

On average, technical efficiency across the 324 farms was 0.77 , ranging from a minimum of 0.11 to a maximum of $1 \cdot 00$ (s.D. $0 \cdot 182$ ). Out of the sample, $0 \cdot 13$ (43 DMU) of the sample was fully technically efficient. The technical efficiency scores were skewed more towards full efficiency, the majority of producers having efficiency scores between 1.00 and 0.60.

\section{Allocative efficiency}

Allocative efficiency averaged $0 \cdot 74$, ranging from $0 \cdot 21$ to $1 \cdot 00$ (s.D. 0.159). Allocative efficiency, like technical efficiency, was also skewed towards full efficiency with the majority of producers having efficiency scores towards the upper boundaries of total efficiency and $0 \cdot 84$ of producers having scores greater than $0 \cdot 60$. In addition, 0.03 of the sample (9 DMU) was fully allocative efficient and were also classified as fully technically efficient.

\section{Economic efficiency}

Overall or economic efficiency averaged 0.57 (range 0.09-1.00; S.D. 0.195). There was a wider overall
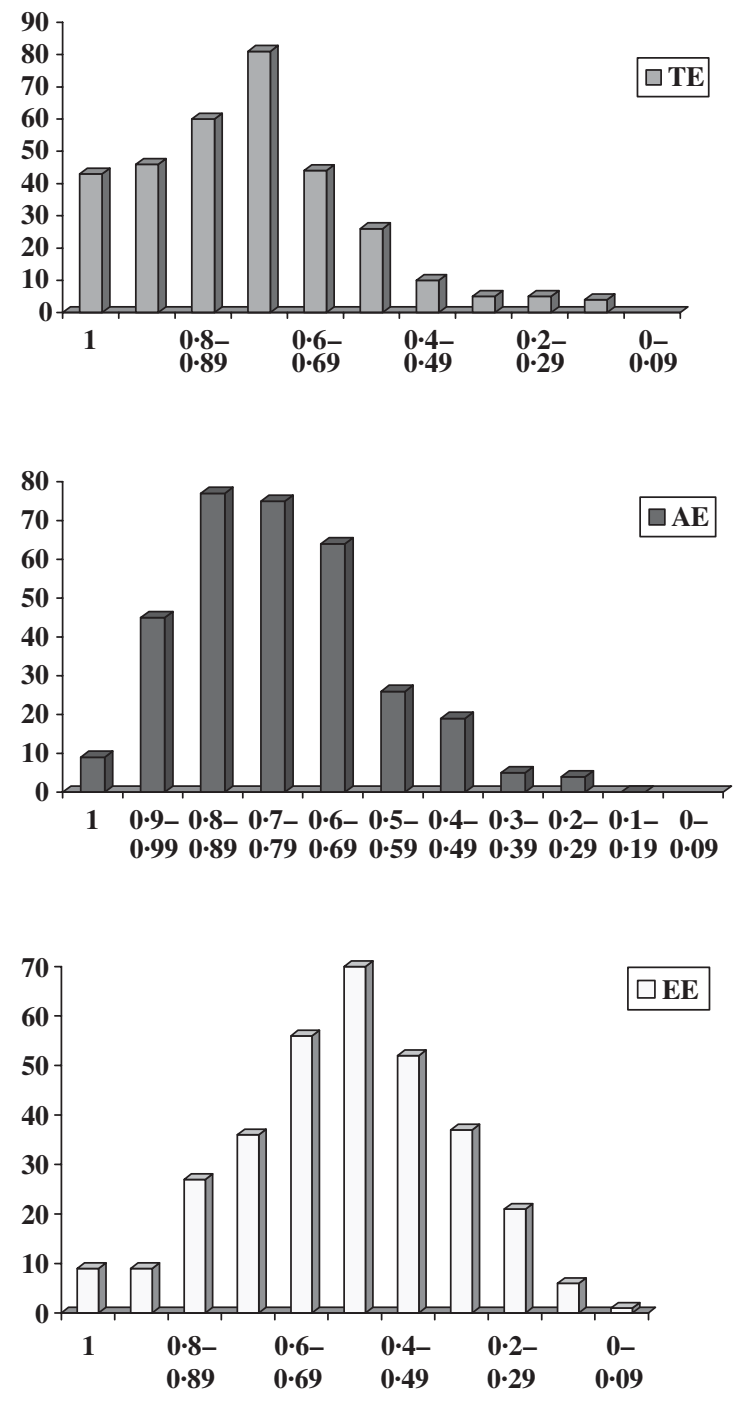

TE (technical efficiency) AE (allocative efficiency) EE (economic efficiency)

Fig. 2. Frequency distribution charts of efficiency scores.

spread in the frequency distribution of economic efficiency scores ranging from 0.09 to 1.00 compared to technical and allocative efficiency which ranged from 0.11 to 1.00 and 0.21 to $1 \cdot 00$, respectively. Therefore, this highlights that economic efficiency was skewed more towards lower levels of efficiency, unlike technical and allocative efficiency. Only 0.03 (9 $\mathrm{DMU}$ ) of all producers were described as being economically efficient and these producers were also allocatively and technically efficient.

\section{Factors affecting efficiency}

In the second stage analysis, a Tobit regression was carried out to investigate the effects of key physical, 
management and demographic variables on technical, allocative and economic efficiency scores. The results are summarized in Tables 5-7, respectively.

\section{Technical efficiency results}

Table 5 presents the results of the regression analysis on the technical efficiency scores.

In model 1, grazing season length and milk bonuses $(P<0.001)$ were positively associated with technical efficiency, while breeding season length $(P<0 \cdot 001)$ had a negative association. Milk penalties was bordering on significance $0 \cdot 1>P>0 \cdot 05$. Level of dairy specialization had no significant association with TE.

In model 2, the addition of milk recording, $\mathrm{Al}$ use and being a member of a discussion group had no significant associations with technical efficiency. Mean calving date was associated with technical efficiency in model 3, with all significant results from model 1 remaining the same. A mean calving date of between 14 and 28 February had a positive association with technical efficiency $(P<0 \cdot 01)$.

In model 4, producers in the highest soil quality class had a significant association with technical efficiency $(P<0 \cdot 01)$. However, the inclusion of soil quality removed the positive association of grazing season length with technical efficiency which may be explained by potential multi-collinearity among certain variables. Producers who were members of a discussion group, although not significantly associated with technical efficiency, did border on significance $(0 \cdot 1>P>0 \cdot 05)$.

Model 5 included demographic variables in the analysis. The results of the final model were similar to model 4. The inclusion of demographic variables resulted in age and age-squared bordering on significance $0 \cdot 1>P>0 \cdot 05$ negatively with technical efficiency. All other variables were not significant.

\section{Allocative efficiency results}

Table 6 presents the results of the regression using the allocative efficiency scores as dependent variables.

In model 1 , greater specialization $(P<0 \cdot 001)$ was found to have a significant positive association with allocative efficiency, while grazing season length and increased milk bonuses bordered on significance $(0 \cdot 1>P>0 \cdot 05)$. Breeding season length and milk penalties had no significant association.
In model 2, the use of milk recording $(P<0.01)$ and Al (bordering on significance $0 \cdot 1>P>0 \cdot 05$ ) were similar to model 1 milk bonuses, and a greater specialization in dairy production led to increased allocative efficiency.

The results in model 3 again resulted in the same associations as in model 2; however, the addition of mean calving date of between 1 and 17 March had a negative association with allocative efficiency, bordering on significance $(0 \cdot 1>P>0 \cdot 05)$.

In model 4 , results were again similar to the previous model when soil quality was included and resulted in a positive association, bordering on significance $(0 \cdot 1>P>0 \cdot 05)$, of producers in the first and second highest soil quality with allocative efficiency.

Model 5 included demographic variables although these were not found to be significantly associated with allocative efficiency. Therefore, results were similar to model 4, with the exception of mean calving date having no significant association with allocative efficiency.

\section{Economic efficiency results}

Table 7 presents the results of the regression using the economic efficiency results as the dependent variables.

In model 1, greater economic efficiency was associated with a longer grazing season length $(P<0 \cdot 001)$, increased milk bonuses $(P<0 \cdot 001)$ and greater specialization $(P<0 \cdot 001)$. Increased breeding season length had a negative association with economic efficiency, bordering on significance $(0 \cdot 1>P>0 \cdot 05)$. The association of milk penalties with economic efficiency was not significant.

In model 2, results were similar to model 1 but the addition of milk recording $(P<0 \cdot 01)$ and using $\mathrm{Al}$ $(P<0.01)$ had significant positive associations with economic efficiency.

In model 3, the inclusion of mean calving date resulted in a positive association, bordering on significance $(0 \cdot 1>P>0 \cdot 05)$, for producers with mean calving between 14 and 28 February with economic efficiency.

In model 4, the addition of soil quality resulted in a positive association of producers in the highest soil quality with economic efficiency (bordering on significance $0 \cdot 1>P>0 \cdot 05$ ). Results were similar to the previous model, apart from the removal of grazing season length, milk bonuses and mean calving date as significant variables associated with economic 
Table 5. Regression results of management, qualitative and demographic factors associated with technical efficiency

\begin{tabular}{|c|c|c|c|c|c|c|c|c|c|c|}
\hline \multirow[b]{2}{*}{ Variable } & \multicolumn{2}{|c|}{ Model 1} & \multicolumn{2}{|c|}{ Model 2} & \multicolumn{2}{|c|}{ Model 3} & \multicolumn{2}{|c|}{ Model 4} & \multicolumn{2}{|c|}{ Model 5} \\
\hline & Estimate & S.E. & Estimate & S.E. & Estimate & S.E. & Estimate & S.E. & Estimate & S.E. \\
\hline Intercept & $-0 \cdot 45$ & $0 \cdot 093$ & $-0 \cdot 36$ & $0 \cdot 098$ & $-0 \cdot 32$ & $0 \cdot 097$ & $-0 \cdot 3$ & $0 \cdot 10$ & $-0 \cdot 3$ & $0 \cdot 13$ \\
\hline Grazing days & $0 \cdot 001$ & $0 \cdot 0004$ & $0 \cdot 001$ & $0 \cdot 0004$ & $0 \cdot 001$ & $0 \cdot 0004$ & $0 \cdot 0002$ & $0 \cdot 00041$ & $0 \cdot 0002$ & $0 \cdot 00041$ \\
\hline Breeding days & $-0 \cdot 001$ & $0 \cdot 0001$ & $-0 \cdot 0004$ & $0 \cdot 00010$ & $-0 \cdot 0003$ & $0 \cdot 00011$ & $-0 \cdot 0003$ & $0 \cdot 00011$ & $-0 \cdot 0003$ & $0 \cdot 00011$ \\
\hline Dairy proportion gross output & 0.06 & $0 \cdot 080$ & $-0 \cdot 05$ & $0 \cdot 084$ & $-0 \cdot 05$ & $0 \cdot 086$ & $-0 \cdot 02$ & $0 \cdot 084$ & $-0 \cdot 03$ & $0 \cdot 084$ \\
\hline Milk recording & & & $0 \cdot 05$ & $0 \cdot 025$ & $0 \cdot 04$ & $0 \cdot 026$ & 0.03 & $0 \cdot 025$ & $0 \cdot 03$ & $0 \cdot 025$ \\
\hline Al use & & & $0 \cdot 01$ & $0 \cdot 027$ & $-0 \cdot 004$ & $0 \cdot 0265$ & $<0 \cdot 001$ & $0 \cdot 0259$ & $0 \cdot 01$ & $0 \cdot 026$ \\
\hline Discussion* & & & $0 \cdot 03$ & $0 \cdot 025$ & $0 \cdot 03$ & $0 \cdot 026$ & $0 \cdot 04$ & $0 \cdot 025$ & $0 \cdot 05$ & $0 \cdot 025$ \\
\hline Mean calving $1+$ & & & & & 0.06 & 0.044 & 0.08 & 0.043 & 0.08 & $0 \cdot 042$ \\
\hline Mean calving 2 & & & & & $0 \cdot 10$ & 0.034 & $0 \cdot 10$ & 0.033 & $0 \cdot 11$ & $0 \cdot 033$ \\
\hline Mean calving 3 & & & & & $0 \cdot 02$ & $0 \cdot 030$ & 0.03 & $0 \cdot 029$ & 0.03 & $0 \cdot 030$ \\
\hline Mean calving 4 & & & & & $0 \cdot 01$ & 0.035 & $0 \cdot 02$ & $0 \cdot 034$ & $0 \cdot 02$ & $0 \cdot 034$ \\
\hline Soil 1‡ & & & & & & & $0 \cdot 11$ & 0.044 & $0 \cdot 11$ & $0 \cdot 043$ \\
\hline Soil 2 & & & & & & & 0.07 & $0 \cdot 049$ & $0 \cdot 05$ & $0 \cdot 048$ \\
\hline Soil 3 & & & & & & & $0 \cdot 08$ & $0 \cdot 048$ & 0.07 & $0 \cdot 048$ \\
\hline Soil 4 & & & & & & & 0.02 & $0 \cdot 045$ & 0.02 & $0 \cdot 045$ \\
\hline Age & & & & & & & & & $0 \cdot 02$ & $0 \cdot 007$ \\
\hline Age squared & & & & & & & & & $-0 \cdot 0002$ & $0 \cdot 00012$ \\
\hline Teagasc client & & & & & & & & & $0 \cdot 03$ & $0 \cdot 023$ \\
\hline Married & & & & & & & & & $-0 \cdot 04$ & $0 \cdot 026$ \\
\hline Off-farm job & & & & & & & & & 0.03 & $0 \cdot 029$ \\
\hline
\end{tabular}

* Discussion group member.

+ Mean calving date: dummy variable, 1 if calving $\leqslant 14$ Feb, 2 if calving $\leqslant 11$ Mar, 3 if calving $\leqslant 117$ Mar, 4 if calving $\leqslant 131$ Mar and 5 if calving $\geqslant 1$ Apr.

₹ Soil quality ranges from 1 to 6 with 1 an indication of best soil with widest range of use and 6 the poorest soil quality with most limited range of use.

Milk penalties were zero in all cases, but bordering on significance in models 1-3 and significant for models 4 and 5 . Milk bonuses were zero in all cases, but were significant throughout all models. 
Table 6. Regression results of management, qualitative and demographic factors associated with allocative efficiency

\begin{tabular}{|c|c|c|c|c|c|c|c|c|c|c|}
\hline \multirow[b]{2}{*}{ Variable } & \multicolumn{2}{|c|}{ Model 1} & \multicolumn{2}{|c|}{ Model 2} & \multicolumn{2}{|c|}{ Model 3} & \multicolumn{2}{|c|}{ Model 4} & \multicolumn{2}{|c|}{ Model 5} \\
\hline & Estimate & S.E. & Estimate & S.E. & Estimate & S.E. & Estimate & S.E. & Estimate & S.E. \\
\hline Intercept & $-0 \cdot 60$ & $0 \cdot 086$ & $-0 \cdot 49$ & $0 \cdot 090$ & $-0 \cdot 50$ & $0 \cdot 094$ & $-0 \cdot 5$ & $0 \cdot 10$ & $-0 \cdot 5$ & $0 \cdot 12$ \\
\hline Grazing days & $0 \cdot 001$ & $0 \cdot 0003$ & $0 \cdot 0001$ & $0 \cdot 00031$ & $0 \cdot 0003$ & $0 \cdot 00042$ & $0 \cdot 0001$ & $0 \cdot 00041$ & $0 \cdot 0001$ & $0 \cdot 00041$ \\
\hline Breeding days & $0 \cdot 0001$ & $0 \cdot 00011$ & $0 \cdot 0001$ & $0 \cdot 00011$ & $<0 \cdot 0001$ & $0 \cdot 00010$ & $<0.0001$ & $0 \cdot 00010$ & $<0 \cdot 0001$ & $0 \cdot 00010$ \\
\hline Dairy proportion gross output & $0 \cdot 33$ & $0 \cdot 076$ & $0 \cdot 22$ & $0 \cdot 077$ & $0 \cdot 23$ & $0 \cdot 077$ & $0 \cdot 24$ & $0 \cdot 078$ & $0 \cdot 24$ & $0 \cdot 078$ \\
\hline Milk recording & & & 0.06 & $0 \cdot 022$ & $0 \cdot 06$ & $0 \cdot 023$ & $0 \cdot 07$ & $0 \cdot 023$ & $0 \cdot 07$ & $0 \cdot 023$ \\
\hline $\mathrm{Al}$ use & & & $0 \cdot 04$ & $0 \cdot 024$ & 0.05 & $0 \cdot 025$ & 0.05 & $0 \cdot 025$ & $0 \cdot 05$ & $0 \cdot 026$ \\
\hline Discussion* & & & $0 \cdot 04$ & $0 \cdot 023$ & $0 \cdot 04$ & $0 \cdot 023$ & $0 \cdot 04$ & $0 \cdot 023$ & $0 \cdot 04$ & $0 \cdot 024$ \\
\hline Mean calving 1† & & & & & $-0 \cdot 03$ & $0 \cdot 041$ & -0.03 & $0 \cdot 041$ & -0.03 & $0 \cdot 041$ \\
\hline Mean calving 2 & & & & & $-0 \cdot 04$ & $0 \cdot 033$ & $-0 \cdot 04$ & $0 \cdot 033$ & -0.04 & $0 \cdot 033$ \\
\hline Mean calving 3 & & & & & $-0 \cdot 05$ & $0 \cdot 028$ & -0.05 & $0 \cdot 028$ & -0.05 & $0 \cdot 029$ \\
\hline Mean calving 4 & & & & & -0.004 & $0 \cdot 0327$ & $-0 \cdot 01$ & $0 \cdot 033$ & -0.007 & $0 \cdot 0329$ \\
\hline Soil $1 \neq$ & & & & & & & 0.07 & $0 \cdot 041$ & $0 \cdot 07$ & $0 \cdot 041$ \\
\hline Soil 2 & & & & & & & $0 \cdot 10$ & $0 \cdot 047$ & $0 \cdot 10$ & $0 \cdot 048$ \\
\hline Soil 3 & & & & & & & 0.04 & $0 \cdot 047$ & $0 \cdot 04$ & $0 \cdot 047$ \\
\hline Soil 4 & & & & & & & $0 \cdot 05$ & $0 \cdot 043$ & $0 \cdot 05$ & $0 \cdot 044$ \\
\hline Age & & & & & & & & & $0 \cdot 001$ & $0 \cdot 0068$ \\
\hline Age squared & & & & & & & & & $<-0.0001$ & $0 \cdot 00010$ \\
\hline Teagasc client & & & & & & & & & -0.007 & $0 \cdot 0225$ \\
\hline Married & & & & & & & & & $0 \cdot 003$ & $0 \cdot 0237$ \\
\hline Off-farm job & & & & & & & & & -0.02 & $0 \cdot 029$ \\
\hline
\end{tabular}

* Discussion group member.

+ Mean calving date: dummy variable, 1 if calving $\leqslant 14$ Feb, 2 if calving $\leqslant 1$ Mar, 3 if calving $\leqslant 17$ Mar, 4 if calving $\leqslant 31$ Mar and 5 if calving $\geqslant 1$ Apr.

\# Soil quality ranges from 1 to 6 with 1 an indication of best soil with widest range of use and 6 the poorest soil quality with most limited range of use.

Milk bonuses were zero in all cases, but bordered on significance in models 1-3. Milk penalties were also zero in all cases, and were not significant. 


\begin{tabular}{|c|c|c|c|c|c|c|c|c|c|c|}
\hline \multirow[b]{2}{*}{ Variable } & \multicolumn{2}{|c|}{ Model 1} & \multicolumn{2}{|c|}{ Model 2} & \multicolumn{2}{|c|}{ Model 3} & \multicolumn{2}{|c|}{ Model 4} & \multicolumn{2}{|c|}{ Model 5} \\
\hline & Estimate & S.E. & Estimate & S.E. & Estimate & S.E. & Estimate & S.E. & Estimate & S.E. \\
\hline Intercept & $-1 \cdot 4$ & $0 \cdot 14$ & $-1 \cdot 2$ & $0 \cdot 15$ & $-1 \cdot 2$ & $0 \cdot 15$ & $-1 \cdot 2$ & $0 \cdot 16$ & $-1 \cdot 0$ & $0 \cdot 19$ \\
\hline Grazing days & $0 \cdot 003$ & $0 \cdot 0005$ & $0 \cdot 002$ & $0 \cdot 0005$ & $0 \cdot 002$ & $0 \cdot 0006$ & $0 \cdot 001$ & $0 \cdot 0006$ & $0 \cdot 001$ & $0 \cdot 0006$ \\
\hline Breeding days & $-0 \cdot 0004$ & $0 \cdot 00021$ & -0.0004 & $0 \cdot 00020$ & -0.0003 & $0 \cdot 00021$ & -0.0003 & $0 \cdot 00021$ & $-0 \cdot 0003$ & $0 \cdot 00021$ \\
\hline Dairy proportion gross output & $0 \cdot 6$ & $0 \cdot 12$ & $0 \cdot 4$ & $0 \cdot 13$ & $0 \cdot 4$ & $0 \cdot 13$ & $0 \cdot 4$ & $0 \cdot 13$ & $0 \cdot 4$ & $0 \cdot 13$ \\
\hline Milk recording & & & $0 \cdot 11$ & $0 \cdot 036$ & $0 \cdot 10$ & $0 \cdot 036$ & $0 \cdot 10$ & $0 \cdot 036$ & $0 \cdot 10$ & $0 \cdot 036$ \\
\hline Al use & & & $0 \cdot 11$ & $0 \cdot 040$ & $0 \cdot 111$ & $0 \cdot 041$ & $0 \cdot 12$ & $0 \cdot 040$ & $0 \cdot 12$ & $0 \cdot 041$ \\
\hline Discussion* & & & $0 \cdot 06$ & $0 \cdot 036$ & $0 \cdot 06$ & $0 \cdot 037$ & $0 \cdot 07$ & $0 \cdot 037$ & $0 \cdot 08$ & $0 \cdot 037$ \\
\hline Mean calving 1† & & & & & $0 \cdot 07$ & $0 \cdot 065$ & $0 \cdot 06$ & $0 \cdot 065$ & $0 \cdot 07$ & $0 \cdot 064$ \\
\hline Mean calving 2 & & & & & $0 \cdot 09$ & $0 \cdot 051$ & $0 \cdot 08$ & $0 \cdot 051$ & $0 \cdot 10$ & $0 \cdot 050$ \\
\hline Mean calving 3 & & & & & $-0 \cdot 006$ & $0 \cdot 0437$ & $0 \cdot 001$ & $0 \cdot 0439$ & $0 \cdot 02$ & $0 \cdot 045$ \\
\hline Mean calving 4 & & & & & $0 \cdot 06$ & $0 \cdot 053$ & $0 \cdot 04$ & $0 \cdot 052$ & $0 \cdot 07$ & $0 \cdot 052$ \\
\hline Soil 1‡ & & & & & & & $0 \cdot 14$ & $0 \cdot 066$ & $0 \cdot 13$ & $0 \cdot 067$ \\
\hline Soil 2 & & & & & & & $0 \cdot 11$ & $0 \cdot 074$ & $0 \cdot 10$ & $0 \cdot 074$ \\
\hline Soil 3 & & & & & & & 0.06 & $0 \cdot 073$ & $0 \cdot 05$ & 0.072 \\
\hline Soil 4 & & & & & & & $0 \cdot 06$ & $0 \cdot 069$ & $0 \cdot 06$ & $0 \cdot 068$ \\
\hline Age & & & & & & & & & 0.03 & $0 \cdot 011$ \\
\hline Age squared & & & & & & & & & $-0 \cdot 0003$ & $0 \cdot 00010$ \\
\hline Teagasc client & & & & & & & & & -0.001 & $0 \cdot 0856$ \\
\hline Married & & & & & & & & & -0.03 & $0 \cdot 038$ \\
\hline Off $=$ farm job & & & & & & & & & $0 \cdot 004$ & $0 \cdot 0458$ \\
\hline
\end{tabular}

7. Regression results of management, quali

* Discussion group member.

+ Mean calving date: dummy variable, 1 if calving $\leqslant 14 \mathrm{Feb}, 2$ if calving $\leqslant 1$ Mar, 3 if calving $\leqslant 17$ Mar, 4 if calving $\leqslant 31$ Mar and 5 if calving $\geqslant 1$ Apr.

₹ Soil quality ranges from 1 to 6 with 1 an indication of best soil with widest range of use and 6 the poorest soil quality with most limited range of use.

Milk bonuses were zero in all cases, but significant throughout all models. Milk penalties were also zero in all cases, but were not significant. 
efficiency. Membership of a discussion group, although not significant, was positively associated with economic efficiency (bordering on significance $0 \cdot 1>P>0 \cdot 05$ ).

The results of model 5 were similar to those of model 4; however, milk bonuses $(P<0 \cdot 001)$ was found to have a positive association with economic efficiency. Mean calving before the end of February was positive and bordering on significance $(0 \cdot 1>P>0 \cdot 05)$. The inclusion of demographic variables resulted in age squared having a negative association $(P<0 \cdot 01)$ with economic efficiency. Age of operator had a positive association with economic efficiency, bordering on significance $(0 \cdot 1>P>0 \cdot 05)$. All other demographic variables had insignificant associations with the levels of economic efficiency.

\section{DISCUSSION}

Methodology

The objectives of the current study were to measure technical, allocative and economic efficiency for a sample of Irish specialist dairy farms and to investigate the associations of key management and demographic characteristics with technical, allocative and economic efficiencies. DEA was the methodology chosen to calculate the efficiency scores. The main advantage of this method is that it does not require the specification of a particular functional form (Coelli et al. 2005). Alternative econometric methods of frontier analysis have been used, such as SFA developed by Aigner et al. (1977) and Meeusen \& van den Broeck (1977). However, unlike DEA, SFA requires a specific functional form such as the Cobb-Douglas function or its generalization, the Translog function, to be specified for the estimation of a frontier. The main advantage of the SFA methodology, however, is that it contains an error term to account for statistical error and noise. The absence of an error term in the DEA model assumes all error, including noise, as inefficiency. On the other hand, DEA has the important advantage of being a nonparametric method and therefore, not requiring the imposition of an assumed functional form for the production technology.

A second-stage analysis was undertaken to identify key management, qualitative and demographic factors associated with technical, allocative and economic efficiency. This was undertaken using the efficiency score as a dependent variable in a Tobit regression analysis. The two-stage process as outlined in the current study has previously been criticized by Simar \& Wilson (2007) on the basis of bias results due to using explanatory variables in the regression that were correlated with those used in the first stage. Coelli et al. (2005) also stressed that estimation results could potentially be biased if there are high correlations between inputs and outputs and the explanatory variables. Simar \& Wilson (2007) suggested bootstrapping techniques to overcome the problem of biased DEA-Tobit results; however, Afonso \& St. Aubyn (2006) found very similar results comparing the DEA-Tobit results and the bootstrapping results. In the current study, to avoid multicolinearity and investigate the stability of model coefficients, variables were introduced in different groupings. This approach has been used previously by Hansson (2008). Previous studies that have utilized the DEA and Tobit regression methodology include Hansson \& Öhlmér (2008) and Barnes (2006).

\section{Inputs and outputs used}

The inputs used in the current study included physical and financial data for land area, cow numbers, labour, concentrate, fertilizer and other direct and overhead costs, which were all allocated to the dairy enterprise only. Consequently, results from the analysis are specifically for dairy enterprise efficiency. The inputs studied represent the important physical and financial inputs on Irish dairy farms and are consistent with previous studies of this kind in the literature. For example, the importance of land availability has been stressed in previous studies (Dillon et al. 2006; O'Donnell et al. 2008) such that once milk quotas are not limiting expansion the next most limiting constraint on most farms in Ireland will be land. Purchased concentrate and fertilizer are two important inputs for Irish dairy farms and they represented 0.43 and 0.19 of direct costs on Irish dairy farms in 2008, respectively (Connolly et al. 1998-2008). Labour is another important input for Irish dairy farms and according to O'Donnell et al. (2008) labour challenges will influence future decisions at farm level in Ireland. Overall, the inputs used in the current study are similar to those used in previous DEA efficiency studies in the literature, including studies by Tauer (1993), Jaforullah \& Whiteman (1999), Barnes (2006), Stokes et al. (2007) and Hansson \& Öhlmér (2008).

Milk solids produced and other dairy output were included as the two output variables. Quantity of milk solids produced is important because all processors 
pay producers either solely on solids produced or on a volume of milk basis with a differential price for solids composition. Other output was also used to show the financial value of livestock sales from the dairy enterprise. Again the output variables in the current study have been predominantly used as outputs in similar studies by Tauer (1993), Jaforullah \& Whiteman (1999), Barnes (2006) and Hansson \& Öhlmér (2008).

\section{Efficiency results}

Technical, allocative and economic efficiency scores generated in the first stage DEA analysis were 0.771, 0.740 and 0.571 , respectively. This highlights that technical efficiency could increase by, on average, $23 \%$ and allocative efficiency by $26 \%$ to become fully efficient. There was a wider spread of economic efficiency and allocative efficiency results compared to the technical efficiency results, highlighting that producers were more technically efficient than allocatively and economically efficient. There were also a greater number of fully technical-efficient producers compared to allocative and economic-efficient producers. As technical efficiency is the maximizing of output from the level of inputs and allocative efficiency is essentially a measure of financial efficiency representing the ability of the producers to utilize the most costeffective mix of inputs in order to produce output, this shows that producers were focusing more on maximizing output than reducing costs. According to Donnellan et al. (2011), Ireland dairy producers have higher full economic costs and are characterized by lower yields in comparison with EU competitor states. This is probably due to the scale of Irish dairy farms, which are smaller than European and international competitors. As the results on average were less than 1 , the efficiency results therefore highlight that on average producers were overusing inputs, therefore were technically and economically inefficient in 2008 and a potential exists to increase efficiency at farm level. This is very important as food demand worldwide is increasing and the Irish dairy industry has set targets for a 50\% increase in dairy output by 2020 (Department of Agriculture, Food and the Marine 2011).

As data for all farmers that had a dairy enterprise was used, farm size varies among producers and therefore scale of production could potentially be a factor contributing to inefficient production. Land area has been found by O'Donnell et al. (2008) as a constraint to expansion at farm level in Ireland. In a previous study, Hansson (2008) found increased land area resulted in increased technical and economic efficiency for Swedish dairy farmers.

Another issue that is potentially impacting the results is policy. Ireland and EU member states currently have a limit on production through the milk quota. According to Burrell (2004), the quota keeps inefficient producers in production. The quota can generate risk factors for producers, with quota availability and the threat of a super levy for over-production, two risk factors associated with quota that may also be influencing efficiency results. However, milk quota is set to be removed in the EU by 2015, which will overcome one of the barriers to expansion at farm level and potentially lead to economies of scale for producers.

Since producers were not fully efficient, this highlights that inputs such as labour were being overused. Labour has already been identified as a potential future problem post-quota, as O'Donovan (2007) found that increasing scale resulted in an increased demand for hired labour. Similarly, O'Donnell et al. (2008) noted that labour challenges will influence future expansion at farm level in Ireland. Another issue regarding labour is that distribution of farm size in the sample was skewed towards smaller farms; therefore, scale is an issue. This is therefore likely to impinge on allocative efficiency, for example having too much labour for the number of cows. Although not analysed in the current study, quality of labour may be potentially another factor contributing to producers overusing labour with more efficient producers having a higher labour quality standard.

The results of the current study were similar to those generated in previous studies among EU member states. In a Swedish study by Hansson \& Öhlmér (2008) using a similar two-stage process, the average technical, allocative and economic efficiency scores were $0 \cdot 865,0 \cdot 752$ and $0 \cdot 645$, respectively. However, it should be noted that other studies may have generated efficiency scores using alternative DEA models, different efficiency measurement techniques and used producers adopting different production systems with climatic and geographical differences. It must also be noted that efficiency results in the analysis presented in the current paper are attributed to the dairy enterprise only.

\section{Key factors associated with efficiency scores}

The association between key management and demographic factors and technical, allocative and 
economic efficiencies was tested using a Tobit regression. The analysis was carried out by characterizing the independent variables into a number of categories. This method was used to explore the stability of the model coefficients given the potential problem of multi-collinearity in a multivariate regression analysis. For example, Al use and milk recording are likely to be correlated, grazing season length and soil quality, breeding season length and mean calving date are all variables considered to be significant in an Irish context, but which are also likely to be correlated. This is shown in the results through the significance levels and standard errors of particular variables in one model $v$. another model.

Management and qualitative parameters

Grazing season length

Grazing season length was positively associated with technical, allocative and economic efficiency in 2008, highlighting both the physical and financial benefits of extending the number of days spent at grass. Increasing the grazing season has been positively associated with increased profitability in a number of previous studies. Producers with a longer grazing season may also have better quality land. Land quality is highlighted in the next section as associated with differences with efficiency. In a previous study, Rougoor et al. (1999) found a positive influence of grassland management on cost reduction and gross margin for Dutch farmers. In a separate study, Hanson et al. (1998) found greater milk production on farms in New York and Pennsylvania with more extensive grazing. In Ireland, the results in the current study mirror those of Shalloo et al. (2004a), who found that grazing season length was associated with differences in profitability and found by comparing two farms on contrasting soil types that a longer grazing season length existed on the farm with better quality soil. Similarly, Dillon et al. (2002) also indicated that a reliance on grazed grass represented an opportunity to reduce costs. In a separate Irish study, Kennedy et al. (2005) found increased milk solids production with increased quantity of grazed grass in the early stage of lactation for spring-calving cows.

\section{Land quality}

Producers had higher levels of efficiency when originating from better quality soil, as defined by the NFS (Connolly et al. 1998-2008). Qualitative differences in land are likely to affect grass growth and utilization. Differences in land quality against the results of Shalloo et al. (2004a), who found differences in technical performance and profitability by comparing a dairy farm in an area with high rainfall on a heavy clay soil to a farm in a lower rainfall area with freedraining soil. Results by $\mathrm{O}^{\prime}$ Neill \& Matthews (2001) found that there were significant effects on efficiency by farming in the East of Ireland compared to the West. Soil quality was also found by Carroll et al. (2007) to have a positive effect on technical efficiency of Irish dairy producers.

\section{Mean calving date}

Producers with mean calving between 14 and 28 February had higher levels of technical and economic efficiency in 2008, highlighting the benefits of an early spring calving season over a later calving season. Early spring calving allows the opportunity to get cows out to grass in early lactation, which significantly increases milk solid outputs and helps reduce costs. Later calving in March had a negative association with allocative efficiency highlighting there were no cost gains from calving in March compared to calving after April in 2008. These findings mirror the results of Smyth et al. (2010), who highlighted the positive effect of early spring calving on cost reductions, therefore matching peak grazing season growth to peak feed demand.

\section{Specialization}

Increased allocative and economic efficiency were associated with increased specialization in dairy production in 2008. In Ireland, specialist dairy farmers constituted the most profitable agricultural system in 2008, followed by dairy and other systems (Connolly et al. 1998-2008). This therefore indicates that by specializing more in the dairy enterprise in 2008 , by increasing the number of dairy cows and dairy output, efficiency levels were enhanced in 2008. According to Shalloo et al. (2004b) dairy specialization can be facilitated through expansion; projections indicated that Irish producers who remained static between 2004 and 2013 would have a 30\% reduction in output, while those producers who expanded could maintain or increase income. Latruffe et al. (2005) also investigated specialization and found Polish producers with increased specialization in livestock to be more efficient compared to crop-based farms. 


\section{Milk quality}

Increased milk bonuses and reduced milk penalties had a positive association on technical, allocative and economic efficiency. The results of poor milk quality on milk production has been highlighted in previous studies including Hortet \& Seegers (1998), who found reductions in milk yield and composition resulting from increased cases of clinical mastitis. In a similar American study, Barbano et al. (1991) found that increased somatic cell count (SCC) in milk reduced protein and fat composition, therefore indicating a negative effect of reduced milk quality on output, while in a Dutch study by Huijps et al. (2008), reduced economic performance was associated with mastitis.

\section{Milk recording and $\mathrm{Al}$}

Producers participating in milk recording were more allocatively and economically efficient. This may be due to the individual productive and qualitative information provided by milk recording.

Milk recording is a decision support service provided to identify individual cow performance, providing information from milk yields to milk quality with the options of economic breeding data (ICBF 2011). Providing this information for individual cows allows identification of the best and worst performing cows. This therefore influences management decisionmaking regarding cows. Increased milk quality among producers may be due to the information provided from milk recording.

\section{Discussion group member}

It was found that all efficiency levels increased where producers were members of a discussion group. This may be due to the regular transfer of knowledge at discussion group meetings, which led to producers being better informed. Similarly, Hansson (2007) found that discussion of dairy production increased allocative and economic efficiency on Swedish dairy farms. Hennessy \& Newman (2010) also found that members of discussion groups in Ireland were more profitable and had a higher number of grazing days, better milk quality and were younger.

\section{Demography}

The age of the farmer was found to have a positive association and age squared was found to have a negative association with technical and economic efficiency. This highlights that technical and economic efficiency increases with age to a peak and then starts to decline. The age profile of the producers in the current study ranged from a minimum of 27 years old to a maximum of 85 years old with producers on average 52 years old. This is similar to an American study by Tauer \& Lordkipanidze (2000), where productivity was found to increase with age until a certain age and then to decrease. The current analysis also found that marital status had no association with efficiency levels, which was also found in a previous Irish study by Carroll et al. (2007). Participation in offfarm employment had no significant association with efficiency, which is also similar to the findings of Carroll et al. (2007). Contact with the extension service was found to have no significant associations with technical, allocative and economic efficiency levels in the current study, which is different to $\mathrm{O}^{\prime}$ Neill et al. (2002) who found a higher technical efficiency with producers who used the extension services $v$. producers who did not.

\section{CONCLUSIONS}

The objectives of the current study were to measure technical, allocative and economic efficiency for a sample of Irish specialist dairy farms and to investigate the associations of key management, qualitative and demographic characteristics with technical, allocative and economic efficiencies. The results highlight that this sample of dairy producers were not fully efficient for 2008 and the implications of these results show that a potential exists to increase efficiency levels through reducing input use and maximizing output. This is important, as the Irish dairy industry is expected to increase outputs after quotas are removed in 2015. Management factors were key to explaining differences in efficiency among producers, while qualitative and demographic differences were also associated with greater technical, allocative and economic efficiency. Management factors such as mean calving date, number of grazing days, breeding season length, milk quality, discussion group membership were all associated with technical and economic efficiency in 2008. Milk recording, Al use and level of dairy specialization were associated with allocative and economic efficiency only. Qualitative differences were also evident between producers as increased soil quality was associated with greater efficiency levels. Age and age squared were the only significant demographic association with the efficiency scores. 
The current study gives an insight into levels of technical, allocative and economic efficiency of Irish milk producers in 2008. It indicates that land quality differences were very important in explaining variation in efficiency levels among farms. Within the set of controllable factors managerial variables were the key determinants of efficiency. However, demographic factors were not found to have an important impact on efficiency. As only one year of data was used in the current study, it would be beneficial to look at efficiency over a period of time to see if the association of the same management factors such as mean calving date and dairy specialization remain constant over a number of years. The issue of economies of scale was not measured in the current study, therefore the measurement of scale efficiency would also add to further analysis.

The authors would like to thank the producers who participated in the National Farm Survey and the staff of the National Farm Survey involved in the collection, recording and analysis of data.

\section{REFERENCES}

Afonso, A. \& St. Aubyn, M. (2006). Cross-country efficiency of secondary education provision: a semi-parametric analysis with non-discretionary inputs. Economic Modelling 23, 476-491.

Aigner, D., Lovell, C. A. K. \& Schmidt, P. (1977). Formulation and estimation of stochastic frontier production function models. Journal of Econometrics 6, 21-37.

Banker, R. D., Charnes, A. \& Cooper, W. W. (1984). Some models for estimating technical and scale inefficiencies in data envelopment analysis. Management Science 30, 1078-1092.

Barbano, D.M., Rasmussen, R.R. \& LynCH, J.M. (1991). Influence of milk somatic cell count and milk age on cheese yield. Journal of Dairy Science 74, 369-388.

BARNES, A. P. (2006). Does multi-functionality affect technical efficiency? A non-parametric analysis of the Scottish dairy industry. Journal of Environmental Management $\mathbf{8 0}$, 287-294.

BurRelL, A. (2004). The 2003 CAP reform: implications for the EU dairy sector. Outlook on Agriculture 33, 15-25.

Carroll, J., Newman, C. \& Thorne, F. (2007). Understanding the Factors that Influence Dairy Farm Efficiency in the Republic of Ireland. RERC Working Paper Series 07-WPRE-06. Carlow, Ireland: Teagasc.

Charnes, A., Cooper, W. W. \& Rhode, E. (1978). A Data Envelopment Analysis Approach to Evaluation of the Program Follow through Experiment in US Public School Education. Research Report HBS 79-23. Boston, MA: Harvard University.
Coelli, T. (1996). A Guide to DEAP version 2.1. A Data Envelopment Analysis (Computer) Program. CEPA Working Paper no. 8/96. Armidale, Australia: University of New South Wales.

Coelli, T.J., Prasada Rao, D.S., O’Donnell, C.J. \& Battese, G. E. (2005). An Introduction to Efficiency and Productivity Analysis Second Edition. New York: Springer.

Connolly, L., Kinsella, A., Quinlan, G. \& Moran, B. (1998-2008). Irish National Farm Surveys. Dublin, Ireland: Teagasc.

Department of Agriculture, Food and The Marine (2011). Implementation of Food Harvest 2020 in the Dairy Sector. Dublin, Ireland: Department of Agriculture, Food and the Marine. Available online at http://www. agriculture.gov.ie/media/migration/farmingsectors/dairy/ RoadmapRevised080211.pdf (verified 2 Feb 2012).

Dillon, P., Crosse, S., O'Brien, B. \& Mayes, R. W. (2002). The effect of forage type and level of concentrate supplementation on the performance of spring-calving dairy cows in early lactation. Grass and Forage Science 57, 212-223.

Dillon, P., Hennessy, T., Shalloo, L., Thorne, F. \& Horan, B. (2006). Long term vision for the Irish Dairy Industry. In New Vision for the Irish Dairy Industry. Proceedings of the Teagasc National Dairy Conference 2006, Limerick and Cavan, Ireland, pp. 16-34. Dublin: Teagasc.

Donnellan, T., Hennessy, T., Keane, M. \& Thorne, F. (2011). Study of International Competitiveness of the Irish Dairy Sector at Farm Level. Dublin, Ireland: Teagasc.

Farrell, M.J. (1957). The measurement of productive efficiency. Journal of the Royal Statistical Society Series A: General 120, 253-281.

Fingleton, W. A. (1995). Comparative costs and returns for milk production in EU countries. In Proceedings of the Annual Conference of the Agricultural Economics Society of Ireland, Dublin, October 1995, pp. 1-24. Dublin, Ireland: AESI.

Hanson, G. D., Cunningham, L. C., Morehart, M.J. \& Parsons, R. L. (1998). Profitability of moderate intensive grazing of dairy cows in the Northeast. Journal of Dairy Science 81, 821-829.

HanssOn, H. (2007). Strategy factors as drivers and restraints on dairy farm performance: evidence from Sweden. Agricultural Systems 94, 726-737.

Hansson, H. (2008). Are larger farms more efficient? A farm level study of the relationships between efficiency and size on specialized dairy farms in Sweden. Agricultural and Food Science 17, 325-337.

Hansson, H. \& ÖHLmér, B. (2008). The effect of operational managerial practices on economic, technical and allocative efficiency at Swedish dairy farms. Livestock Science 118, 34-43.

Hennessy, T. \& Newman, C. (2010). The benefits of the membership of a dairy farm discussion group: evidence from the Irish National Farm Survey. In Dairying: Entering a Decade of Opportunity. Proceedings of the Teagasc National Dairy Conference, Charleville/Mullingar, Ireland, 17th and 18th November 2010 (Ed. Teagasc), pp. 34-40. Oak Park, Co. Carlow, Ireland: Teagasc. 
Hoff, A. (2007). Second stage DEA: comparison of approaches for modelling the DEA score. European Journal of Operational Research 181, 425-435.

Hortet, P. \& SeEGERs, H. (1998). Loss in milk yield and related composition changes resulting from clinical mastitis in dairy cows. Preventive Veterinary Medicine 37, 1-20.

HuIJPS, K., LAM, T. J. \& Hogeveen, H. (2008). Costs of mastitis: facts and perception. Journal of Dairy Research 75, 113-120.

Irish Cattle Breeding Federation (ICBF) (2011). Milk Recording as a Decision Support System for the Commercial Farmer: Ireland Developments. Bandon, Ireland: ICBF. Available online at http://www.icbf.com/ services/milkrecording/overview/index.php (verified 3 Feb 20120).

JAFORULlah, M. \& Whiteman, J. (1999). Scale efficiency in the New Zealand dairy industry: a non-parametric approach. Australian Journal of Agricultural and Resource Economics 43, 523-541.

Kelly, E., Shalloo, L., Geary, U., Kinsella, A. \& Wallace, M. (2011). An application of DEA to measure technical efficiency on a sample of Irish dairy farms. In Summary of Papers Presented at the Agricultural Research Forum 2011, Held at The Tullamore Court Hotel, Tullamore, Co. Offaly, 14 and 15 March 2011, p. 75. Tullamore, Co. Offaly, Ireland: Agricultural Research Forum.

Kennedy, E., O'Donovan, M., Murphy, J.P., Delaby, L. \& O'MARA, F. (2005). Effects of grass pasture and concentrate based feeding systems for spring calving dairy cows in early spring on performance during lactation. Grass and Forage Science 60, 310-318.

Latruffe, L., Balcombe, K., Davidova, S. \& Zawalinska, K. (2005). Technical and scale efficiency of crop and livestock farms in Poland: does specialization matter? Agricultural Economics 32, 281-296.

Meeusen, W. \& Van Den Broeck, J. (1977). Efficiency estimation from Cobb-Douglas production functions with composed error. International Economic Review 18, 435-444.

O'Brien, L. (2011). The challenge of global food security. T Research 6, 8-9. Available online at http://www.teagasc. ie/publications/2011/1002/TResearch_201106.pdf (verified 3 Feb 2012).

O’Donnell, S., Shalloo, L., Butler, A. M. \& Horan, B. (2008). A survey analysis of opportunities and limitations of Irish dairy farmers. Journal of Farm Management 13, 419-434.

O'Donovan, K. (2007). Labour efficiency on Irish dairy farms. PhD thesis, University College, Dublin.

O'Neill, S. \& Matthews, A. (2001). Technical change and efficiency in Irish agriculture. Economic and Social Review 32, 263-284.
O'Neill, S., Leavy, A. \& Matthews, A. (2002). Measuring productivity change and efficiency on Irish farms. Farm and Food 12, 4-5.

Rougoor, C. W., Trip, G., Huirne, R. B. M. \& Renkema, J. A. (1998). How to define and study farmers' management capacity: theory and use in agricultural economics. Agricultural Economics 18, 261-272.

Rougoor, C. W., Vellinga, T. V., Huirne, R. B. M. \& Kuipers, A. (1999). Influence of grassland and feeding management on technical and economic results of dairy farms. NJAS Wageningen Journal of Life Sciences 47, 135-151.

SAS Institute (2006). SAS User's Guide: Statistics. Version 9.1. Cary, NC: SAS Institute.

Shalloo, L., Dillon, P., O'lOUGHlin, J., Rath, M. \& Wallace, M. (2004a). Comparison of a pasture-based system of milk production on a high rainfall, heavy-clay soil with that on a lower rainfall, free-draining soil. Grass and Forage Science 59, 157-168.

Shalloo, L., Dillon, P., Rath, M. \& Wallace, M. (2004b). The Luxembourg common agricultural policy reform agreement: Irish dairy farmer's development options. Journal of Farm Management 12, 911-104.

SIMAR, L. \& WILSON, P. W. (2007). Estimation and inference in two-stage, semi-parametric models of production processes. Journal of Econometrics 136, 31-64.

Smyth, P., Butler, A. M. \& Hennessy, T. (2009). Explaining the variability in the economic performance of Irish dairy farmers 1998-2006. Journal of International Farm Management 4, 1-18. Available online at www.ifmaonline.org/pdf/journals/Vol_4_Ed4_Smyth_etal.pdf (verified 3 Feb 2012).

Smyth, P., Harte, L. \& Hennessy, T. (2010). Seasonality and Costs of Production on Irish Dairy Farms from 1994-2008. The Rural Economy Research Centre, Working Paper Series, Working Paper, 10-WP-RE-01. Dublin: Teagasc.

StOkes, J. R., Tozer, P.R. \& Hyde, J. (2007). Identifying efficient dairy producers using data envelopment analysis. Journal of Dairy Science 90, 2555-2562.

TAUER, L. W. (1993). Short-run and long-run efficiencies of New York dairy farms. Agricultural and Resource Economics Review 22, 1-9.

TAUer, L. W. \& LORDKIPANidze, N. (2000). Farmer efficiency and technology use with age. Agricultural and Resource Economics Review 29, 24-31.

TAUeR, L.W. \& MishrA, A. K. (2006). Dairy farm cost efficiency. Journal of Dairy Science 89, 4937-4943.

ThORne, F. S. (2004). Measuring the Competitiveness of Irish Agriculture (1996-2000). The Rural Economy Research Series No. 9. Dublin: Teagasc. 